\title{
ANALISIS PENGARUH KETERAMPILAN PROSES SAINS TERHADAP PENGUASAAN KONSEP FISIKA SISWA
}

\author{
Hendrik Siswono \\ Institut Keguruan dan Ilmu Pendidikan PGRI Jember, Indonesia
}

\begin{abstract}
Abs tract
Learning Physics that most natural phenomena are required to understand knowledge contextually. This requires a scientific approach to science to improve and develop students' achievement knowledge. Increased knowledge of student concepts can be seen through. Learning Physics urgently requires process skills to improve students' knowledge. The purpose of this study is to determine the relationship of mastery of students' physics concepts. This research method uses literature review from previous research by using descriptive analysis based on variable regression. The results showed, the process of mastering students' physics concepts. This is done by each indicator. Effective for students' development and cognitive, psychomotoric, and affective.
\end{abstract}

Keywords: conceptual mastery; physics learning; science process skills

\begin{abstract}
Abstrak
Pembelajaran Fisika yang sebagian besar fenomena alam dituntut untuk memahami pengetahuan secara kontekstual. Hal ini memerlukan pendekatan sains secara ilmiah untuk meningkatkan dan mengembangkan pengetahuan yang dialami siswa. Peningkatan pengetahuan konsep siswa dapat dilihat melalui keterampilan proses sains siswa. Pembelajaran Fisika sangat memerlukan keterampilan proses sains untuk meningkatkan pengetahuan siswa. Tujuan penelitian adalah mengetahui hubungan keterampilan proses sains terhadap penguasaan konsep Fisika siswa. Metode penelitian ini menggunakan kajian literatur dari penelitian sebelumnya dengan menggunakan analisis deskriptif berdasarkan nilai regresi variabel. Hasil penelitian menunjukkan bahwa keterampilan proses sains berpengaruh terhadap penguasaan konsep Fisika siswa. Hal ini dipengaruhi oleh tiap indikator keterampilan proses sains yang mampu mengembangkan dan meningkatkan aspek kognitif, psikomotorik, dan afektif siswa.
\end{abstract}

Kata Kunci: keterampilan proses sains; pembelajaran fisika; penguasaan konsep

DOI : http://dx.doi.org/10.21067/mpej.v1i2.1967

Diterima: Agustus 2017; Disetujui: September 2017

\section{PENDAHULUAN}

Pendidikan di Indonesia dituntut untuk mengutamakan proses pembelajaran yang bermakna. Pembelajaran menjadi bermakna jika siswa dapat memahami pelajaran dengan menghubungkan materi

\footnotetext{
* Corresponding Author: hendriksiswono@gmail.com
}

dalam kehidupan sehari-hari yang dilakukan dengan metode ilmiah (Wilhelm dkk, 2007). Proses pembelajaran bermakna juga dapat diartikan sebagai adanya proses interaksi siswa dengan guru melalui sumber belajar yang terjadi pada lingkungan belajar (Depdiknas, 2013). 
Terlibatnya siswa dalam proses pembelajaran sangat penting terutama untuk mengkontruksi pengetahuan, penyelidikan masalah, mengolah dan menemukan solusi pemecahannya (Permendiknas, 2006). Salah satunya adalah pembelajaran sains. Pembelajaran sains hakekatnya sebuah kumpulan pengetahuan, strategi berpikir, dan prosedur untuk penyelidikan (Collete \& Chiappetta, 1994). Pembelajaran sains mempunyai presepsi bahwa sains adalah sebuah produk, sains sebagai sikap, dan sains sebagai proses. Hal ini berlaku pada semua pembelajaran bidang sains antara lain, Fisika, Biologi, dan Kimia.

Khususnya pada pembelajaran Fisika, siswa dituntut dapat memahami dan mempunyai keterampilan proses dalam melaksanakannya. Hal ini berkaitan dengan materi Fisika yang sebagian besar adalah fenomena alam (Aji dkk, 2017) dengan penyelidikan dan penemuan. Menurut Prihatiningtyas (2013) bahwa pengetahuan tentang Fisika, konsep dan gagasan ilmiah diperoleh dari serangkaian pengalaman yang dilakukan dengan mengkontruksi fenomena di dalamnya. Proses konstruksi konsep didasarkan pada keterampilan proses yang dimiliki oleh siswa. Semakin meningkat keterampilan proses yang dimiliki maka semakin baik struktur konsep yang diperoleh, dan semakin menurun keterampilan proses yang dimiliki maka semakin sempit struktur konsep yang diperoleh.
Keterampilan proses sains dalam pembelajaran Fisika berperan penting dalam proses penemuan dan pemahaman konsep. Pembelajaran dapat dilakukan melalui praktikum maupun demonstrasi. Keterlibatan siswa dalam praktikum mampu memaksa siswa untuk memunculkan dan mengembangkan potensi keterampilan proses sains secara ilmiah pada diri siswa terutama meningkatkan aspek kognitif, psikomotorik, dan afektif. Menurut Lightburn (2007) bahwa keterampilan proses sains merupakan faktor penting yang mempengaruhi hasil belajar siswa.

Proses pembelajaran Fisika lebih difokuskan pada keaktifan siswa, pada umumnya guru cenderung menyampaikan informasi hanya satu arah melalui ceramah saja. Penumpukan informasi dan konsep saja tanpa ada penyelidikan ilmiah yang membuat siswa hanya menghafal tanpa memahami materi yang diberikan. Pembelajaran menggunakan metode ceramah tidak cocok digunakan dalam pembelajaran Fisika karena siswa tidak berperan aktif, berkurangnya kemampuan berpikir, bekerja dan bersikap ilmiah serta berkomunikasi antar siswa. Menurut Setyorini (2011) permasalahan ini disebabkan guru cenderung menggunakan ceramah karena keterbatasan waktu mengajar, target materi dan sarana prasarana yang kurang memadai sehingga pembelajaran menjadi proses yang monoton dan pasif yang berdampak pada siswa. 
Penguasaan konsep Fisika yang kuat didasarkan pada proses penyampaian informasi yang kuat pula. Informasi dapat disampaikan secara tertulis dan pengamatan panca indera. Kegiatan informasi penyampaian melalui panca indera antara lain adalah menghitung, mengukur, membaca, melihat, dan mendengar. Pada pembelajaran Fisika, kegiatan belajar melalui panca indera salah satunya dapat muncul melalui kegiatan praktikum dan tidak hanya secara panca indera melainkan semua aspek psikomotorik, afektif dan kognitif dapat dimunculkan secara ilmiah.

Berkaitan dengan keterampilan proses sains bahwa pengetahuan yang diantaranya diperoleh dari panca indera dapat digunakan untuk memperoleh dan memproses pengetahuan, serta membentuk keterampilan berpikir (Markawi, 2015). Menurut Whyne dan Beyer dalam Markawi (2015) keterampilan proses sains juga merupakan prosedur yang digunakan untuk mencari dan mengolah informasi serta alat untuk memahami materi. Keterampilan proses sains membantu siswa belajar, mendapatkan penemuan serta cara dan metode meneliti, siswa lebih aktif, meningkatkan tanggungjawab dan membantu dalam memahami pelajaran, dan meningkatkan kesadaran untuk bertanggungjawab atas pengetahuan mereka sendiri (Aktamis, 2009). Pada prosesnya siswa dididik dan dilatih untuk terampil dalam memperoleh dan mengolah informasi melalui aktivitas berpikir dengan mengikuti prosedur (metode) ilmiah, seperti terampil melakukan pengamatan, pengukuran, pengklasifikasian, penarikan kesimpulan, dan pengkomunikasian hasil temuan (Haryono, 2006).

Karakteristik keterampilan proses sains tersebut dikembangkan menjadi indikator dari keterampilan proses sains yakni, menuliskan rumusan masalah, identifikasi besaran fisika, menuliskan hipotesis, merancang alat percobaan, menentukan langkah percobaan, menggunakan alat percobaan, berkomunikasi atau berdiskusi, menuliskan data pengamatan, menuliskan hasil penghitungan data, menyajikan hasil percobaan, menuliskan analisis dan pembahasan, dan menyimpulkan. Indikator tersebut memuat aspek kognitif, psikomotorik dan afektif. Penelitian ini membahasa tentang analisis pengaruh keterampilan proses sains terhadap penguasaan konsep Fisika siswa.

\section{METODE PENELITIAN}

Penelitian ini $r \begin{array}{r}\text { merupakan } \\ \text { literatur }\end{array}$
menelitian studi
ada dan penelitian sebelumnya
sebagai acuan kajian data penelitian.
Alur studi literatur mengacu pada
Gambar 1.




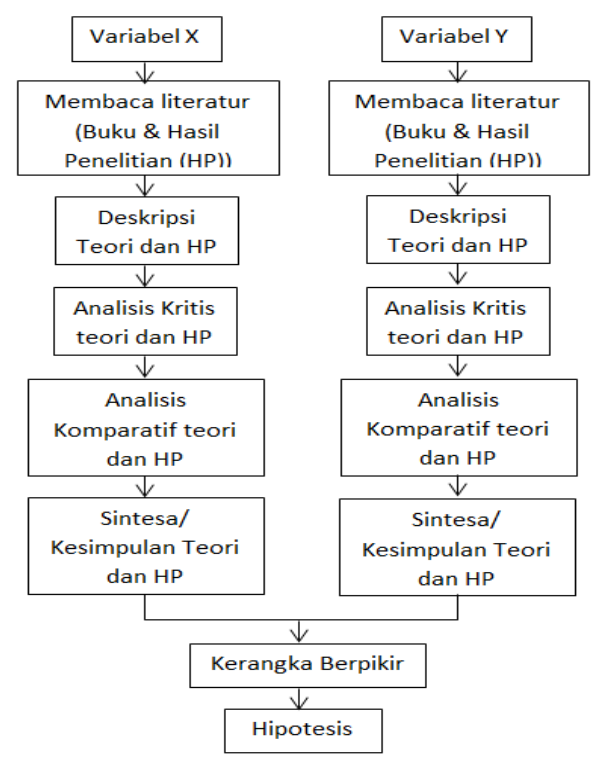

Gambar 1. Bagan Alir Studi Literatur (Sugiyono, 2010)

Data penelitian diperoleh dari hasil penelitian oleh peneliti sendiri yang mengkaji tentang pengaruh problem based learning (PBL) berbantuan kombinasi virtual dan real laboratory terhadap keterampilan proses sains dan penguasaan konsep fisika siswa. Subjek dari data penelitian sebelumnya adalah siswa kelas X SMA Negeri 1 Lumajang Tahun 2013/2014. Penelitian ini dilaksanakan pada semester genap dengan jumlah 2 kelas dan sampel penelitian yang digunakan yaitu kelas X3 dan X7. Teknik analisis data yang digunakan dalam kajian penelitian ini menggunakan analisis regresi linier sederhana untuk melihat hubungan pengaruh keterampilan proses sains terhadap penguasaan konsep fisika siswa. Hasil kajian berupa analisis deskriptif berdasarkan nilai determinasi regresi (R-square) pada keterampilan proses sains dan penguasaan konsep siswa. Rentang nilai R-square antara 0-1 dan determinasi regresi dinyatakan signifikan jika nilai semakin mendekati 1 dan kurang signifikan jika semakin menjauhi nilai 1 .

Analisis pengaruh keterampilan proses sains terhadap penguasaan konsep fisika siswa pada penelitian ini mengkaji hasil hubungan antar variabel (keterampilan proses sains dan penguasaan konsep siswa) secara deskriptif.

\section{HASIL DAN PEMBAHASAN}

Berdasarkan penelitian yang dilakukan sebelumnya diperoleh analisis keterampilan proses sains dan penguasaan konsep fisika siswa, terlihat bahwa hasil keterampilan proses sains siswa berpengaruh pada hasil penguasaan konsep fisika siswa.

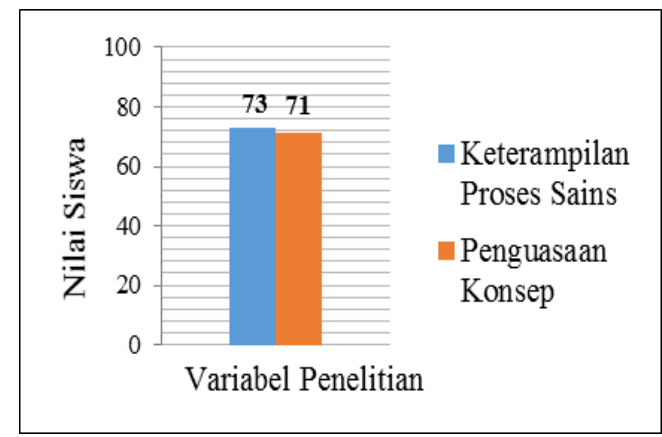

Gambar 2. Grafik Rata-Rata Nilai Keterampilan Proses Sains dan Penguasaan Konsep Fisika Siswa Kelas X.3 (Siswono, 2015)

Dari hasil rata-rata nilai siswa pada setiap kelas pada Gambar 2 dan 3 diperoleh hasil yang signifikan dari kelas X.3 dan X.7. Terdapat 
hubungan yang linier antara keterampilan proses sains dan penguasaan konsep fisika siswa. Hasil analisis pengaruh keterampilan proses sains dan penguasaan konsep siswa dapat ditunjukkan pada Gambar 3.

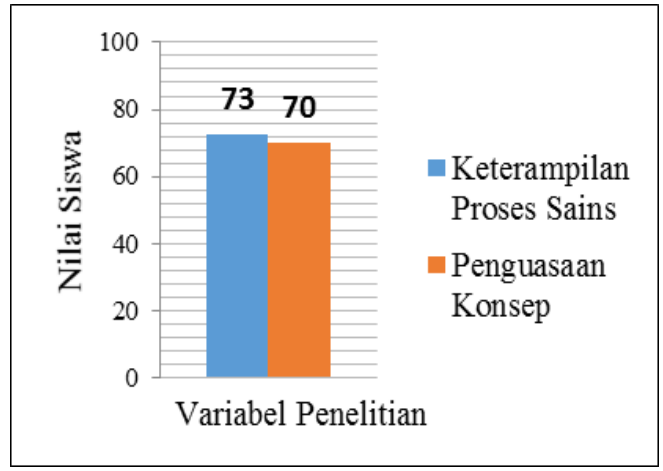

Gambar 3. Grafik Rata-Rata Nilai Keterampilan Proses Sains dan Penguasaan Konsep Fisika Siswa Kelas X.7 (Siswono, 2015)

Berdasarkan tabel 1 maka diperoleh nilai R-square 0,8450 pada kelas X.3 dan 0,7289 pada kelas X.7. Hal ini berarti semakin mendekati nilai $\mathrm{R}=1,00$ menunjukkan bahwa keterampilan proses sains siswa berpengaruh secara signifikan terhadap penguasaan konsep fisika siswa. Hasil ini berlaku pada kedua kelas penelitian yang sama memiliki nilai $\mathrm{R}$-square mendekati 1,00 .

Tabel 1. Analisis Regresi Linear

\begin{tabular}{ccc}
\hline Kelas & $\begin{array}{c}\text { Statistik } \\
\text { Regresi }\end{array}$ & Signifikansi \\
\hline X.3 & R-Square & 0,8450 \\
X.7 & R-Square & 0,7289 \\
\hline
\end{tabular}

Hasil analisis data yang telah dijelaskan di atas menunjukkan bahwa keterampilan proses sains siswa memiliki hubungan yang signifikan dengan penguasaan konsep fisika siswa. Keterampilan proses sains bertujuan untuk membangun pengetahuan yang ada dalam diri siswa melalui kegiatan yang melibatkan pengetahuan kognitif, psikomotorik dan afektif (sosial). Menurut Nurhayati (2011) bahwa keterampilan proses sains merupakan keseluruhan dari keterampilan ilmiah yang terarah (baik kognitif maupun psikomotor) yang dapat digunakan untuk menemukan suatu konsep atau teori, untuk mengembangkan konsep yang telah ada sebelumnya. Kontruksi pengetahuan akan muncul melalui pengorganisasian informasi yang dilakukan ketika siswa mencapai indikator keterampilan proses sains (Arends, 2013). Indikator keterampilan proses sains terbagi beberapa aspek, diantaranya aspek kognitif, psikomotorik, dan afektif (sosial). Menurut beberapa peneliti (Mweene, 2012; Ozgelen, 2012; Subagyo, 2009; Yokhebed, 2012; Ango, 2002) bahwa contoh Indikator dalam aspek kognitif mencakup beberapa indikator yakni, membuat rumusan masalah, merumuskan hipotesis, menganalisis hasil pengamatan, membahas hipotesis, menyimpulkan. Beberapa contoh indikator aspek psikomotorik antara lain, menyiapkan alat dan bahan, merancang alat percobaan, menggunakan alat ukur, dan mengembalikan alat percobaan. Beberapa contoh indikator aspek afektif (sosial) antara lain, berkomunikasi, berdiskusi. Semua aspek indikator keterampilan proses sains ini sangat mempengaruhi penguasaan konsep atau pengetahuan siswa sesuai dengan apa yang mereka temukan secara ilmiah. Hal ini didukung oleh penelitian Silaban 
(2014) bahwa penguasaan konsep dilakukan oleh siswa dalam menerima dan mentransfer kembali sejumlah informasi materi yang dapat dipergunakan untuk solusi memecahkan masalah, menganalisis, menginterpetasikan suatu fenomena yang diamati. Hal tersebut menjelaskan bahwa penguasaan konsep sangat membutuhkan keterampilan proses yang lebih aktif dan sesuai dengan metode ilmiah sehingga siswa dapat memperoleh konsep yang akurat dan lebih matang.

Keterampilan proses sains dapat dikembangkan melalui kegiatan eksperimen. Hampir semua aspek keterampilan proses sains muncul di dalam kegiatan eksperimen sains. Penelitian Hamida (2013) membuktikan bahwa siswa saat merangkai alat dan bahan eksperimen, mengenali dan menggunakan alat ukur pada saat eksperimen akan lebih aktif berinteraksi dan berdiskusi antar siswa sehingga memperoleh hasil pembahasan yang lebih tepat. Keterlibatan kegiatan untuk belajar khususnya melalui eksperimen memungkinkan siswa menemukan prinsip mereka sendiri untuk memperoleh pengetahuannya (Chini, 2012). Keterampilan proses sains siswa sangat berpengaruh terhadap penguasaan konsep siswa khususnya dalam pembelajaran fisika. Hal ini dijelaskan dalam uraian yang telah dijelaskan diatas yang menjadikan keterampilan proses sains siswa sebagai acuan dalam perolehan pengetahuan baik dalam konsep maupun eksperimen.

\section{SIMPULAN}

Hasil analisis deskriptif pengaruh keterampilan proses sains terhadap penguasaan konsep fisika siswa sangat signifikan. Keterampilan proses sains memberikan pengaruh yang positif terhadap penguasaan konsep fisika siswa yang dibuktikan melalui analisis teoritis dan empiris. Hasil penelitian dapat dikembangkan dengan menfokuskan pada salah satu aspek keterampilan proses sains yaitu aspek kognitif, psikomotorik dan afektif (sosial).

\section{DAFTAR PUSTAKA}

Aji, S. D, Hudha, M. N \& Rismawati, A. Y. (2017). Pengembangan Modul Pembelajaran Fisika

Berbasis Problem Based Learning untuk Meningkatkan Kemampuan Pemecahan Masalah Fisika. Science Education Journal, 1(1), 36-51.

Aktamis, H., Ergin, O. 2008. The Effect of Science Process Skills Education on Students' Scientific Creativity, Science Attitudes and Academic Achievments. Asie-Pasific on Science Learning and Teaching. Vol. 9, Issue 1, Article 4, p. 1.

Ango, ML. 2002. Mastery of Science Process Skills and Their Effective Use in The Teaching of Science: An Educology of Science Education in the Nigerian Context. International Journal of Educology, 16(1): 11-30.

Arends, R. 2013. Belajar untuk Mengajar (Learning to Teach). Jakarta: The Mc 
Graw-Hill Education (Asia) dan Salemba Empat.

Chini, J., Madsen, A., Gire, E., Rebello, N.S., \& Puntambekar, S. 2012. Exploration Of Factors That Affect The Comparative Effectiveness Of Physical And Virtual Manipulatives In An Undergraduate Laboratory. Physical Review Special Topics Physics Education Research, 8(1): 1-12.

Collete \& Chiappetta, E.L. 1994. Science Instruction in the Middle and Secondary Schools (3rd ed). New York. Merril

Departemen Pendidikan Nasional. 2002. Kurikulum dan Hasil Belajar Kompetensi Dasar Mata Pelajaran Fisika. Jakarta: Balitbang Depdiknas.

Hamida, N., Mulyani, B., \& Utami, B. 2013. Studi Komparasi Penggunaan Laboratorium Virtual Dan Laboratorium Riil Dalam Pembelajaran Student Teams Achievement Division (STAD) Terhadap Prestasi Belajar Ditinjau Dari Kreativitas Siswa Pada Materi Pokok Sistem Koloid Kelas XI Semester Genap SMA Negeri 1 Banyudono Tahun Pelajaran 2011/2012. Jurnal Pendidikan Kimia, 2(2): 7-15. ISSN: 23379995.

Haryono. 2006. Model Pembelajaran Berbasis Peningkatan Ketrampilan Proses Sains. Jurnal Pendidikan Dasar, 7 (1), 1-13.
Lightburn, M. E., \& Fraser, B. J. 2007. Classroom Environment and Student Outcomes among Students Using Anthropometry Activities in High-School Science. Research in Science \& Technological Education, 25(2): 53-166.

Markawi, N. 2015. Pengaruh Keterampilan Proses Sains, Penalaran, dan Pemecahan Masalah Terhadap Hasil Belajar Fisika. Jurnal Formatif. 3(1): 11-25. ISSN: 2088-351X

Mweene, V., Mumba, F., Mbewe, S. 2012. How Pre-Service Teachers' Understand And Perform Science Process Skill. Eurasia Journal of Mathematics, Science \& Technology Education. 8(3), 167-176.

Nurhayati, 2011. Pembelajaran Konsep Kalor Melalui Kegiatan Laboratorium Desain untuk Meningkatkan Penguasaan Konsep dan Keterampilan Proses Sains Siswa SMA. Tesis tidak diterbitkan. Bandung: UPI.

Ozgelen, S. 2012. Students' Science Process Skills Within A Cognitive Domain Framework. Eurasia Journal of Mathematics, Science \& Technology Education. 8(4), 283-292.

Permendiknas. 2006. Peraturan Menteri Pendidikan Nasional Republik Indonesia Nomor 22 Tahun 2006 Tentang Standar Isi untuk Satuan Pendidikan Dasar dan Menengah. Jakarta. Permendiknas. 
Prihatiningtyas, S., Prastowo, T., \& Jatmiko, B. 2013. Implementasi Simulasi PhET dan Kit Sederhana Untuk Mengajarkan Keterampilan Psikomotor Siswa Pada Pokok Bahasan Alat Optik. Jurnal Pendidikan IPA Indonesia, 2 (1): 18-22.

Setyorini, U., Sukiswo, S., \& Subali, B. 2011. Penerapan Model Problem Based Learning Untuk Meningkatkan Kemampuan Berpikir Kritis Siswa SMP. Jurnal Pendidikan Fisika Indonesia. 7: 52-56. ISSN: 1693-1246.

Silaban, B. 2014. Hubungan Antara Penguasaan Konsep Fisika Dan Kreativitas Dengan Kemampuan Memecahkan Masalah Pada Materi Pokok Listrik Statis. Jurnal Penelitian Bidang Pendidikan, 20(1): $65-75$. ISSN: 0852-0151.

Siswono, H. 2015. Pengaruh Problem Based Learning Berbantuan Kombinasi Real Laboratory dan Virtual Laboratory terhadap Keterampilan Proses Sains dan Penguasaan Konsep Siswa di SMA Negeri 1 Lumajang. Malang: Universitas Neggeri Malang-Tesis tidak diterbitkan.

Subagyo, Y., Wiyanto, P., \& Marwoto. 2009. Pembelajaran Dengan Pendekatan Keterampilan Proses Sains Untuk Meningkatkan Penguasaan Konsep Suhu dan Pemuaian. Jurnal Pendidikan Fisika
Indonesia, 5: 42-46. ISSN: 1693-1246.

Sugiyono. 2010. Metode Penelitian Pendidikan. Bandung: Alfabeta

Wilhelm, J., Thacker, B., \& Wilhelm, R. 2007. Creating Constructivist Physics for Introductory University Classes. Electronic Journal of Science Education, 11(2): 19-37.

Yokhebed, Sudarisman, S., \& Sunarno, W. 2012. Pembelajaran Biologi Menggunakan Model Pembelajaran Berbasis Masalah dengan Pendekatan Keterampilan Proses Sains untuk Meningkatkan Motivasi Belajar dan Hasil Belajar. Jurnal Inkuiri, 1(3): 183-194. ISSN: 2252-7893. 